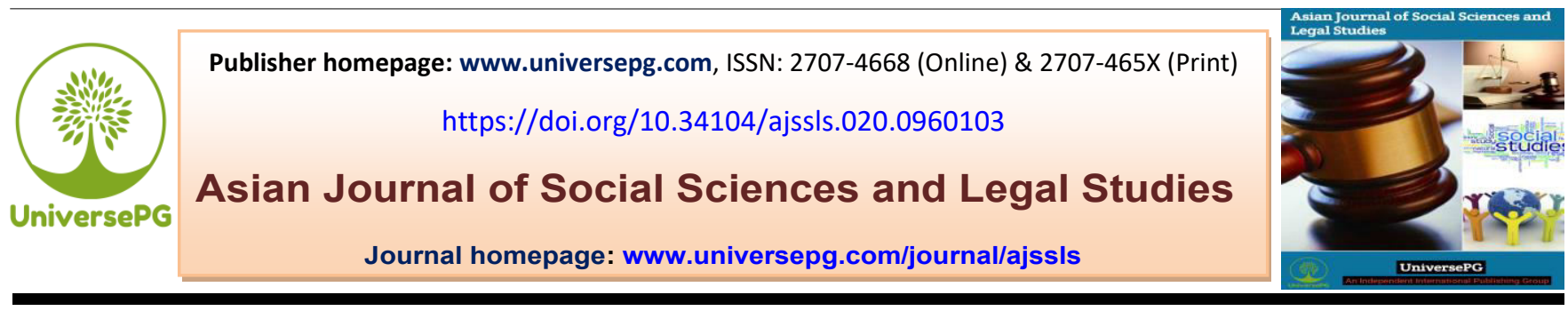

\title{
Study on the Importance of Open Space Due to Create Dhaka as a Child Friendly City
}

\author{
Sharif Tousif Hossain ${ }^{1} *$ and Zarin Tasnim ${ }^{2}$ \\ ${ }^{1}$ Department of Architecture, Stamford University Bangladesh, Dhanmondi, Dhaka, Bangladesh; and ${ }^{2}$ Department of Urban \\ and Regional Planning, Bangladesh University of Engineering and Technology, Dhaka, Bangladesh. \\ *Correspondence: imon_architecture@yahoo.com (Sharif Tousif Hossain, Senior Lecturer, Department of Architecture, \\ Stamford University Bangladesh, Dhanmondi, Dhaka, Bangladesh).
}

\begin{abstract}
Though open spaces are considered a lifeline not just for urban residents but also for children's physical and mental development, Dhaka city is alarmingly losing its parks, playgrounds, and other public spaces to people for numerous causes, such as interference, lack of proper preparation, political and economic power, or simply due to the incompetence and corruption of city officials. This research paper aims to study on open spaces like the playground, parks, and amusement parks in Dhaka which is an important element due to creating a childfriendly city. There is no proper planning and guideline of open spaces for children in Dhaka where e importance of play for a child's cognitive, social, physical, and emotional development has been recognized by researchers worldwide. Children's need to open space to play, learn, exercise, leisure, which is very important for the growth of children's and the training of cognitive, affective, and psychomotor skills, to be able to grow and develop properly. Dhaka lacks these sufficient open spaces for children and will strive to build a childfriendly atmosphere immediately.
\end{abstract}

Keywords: Open spaces, Child friendly environment, Children, Importance of open space, and Dhaka.

\section{INTRODUCTION:}

Open space can be defined as undeveloped land within a city that provides environmental, social and economic benefits to communities that cover water bodies and land dedicated to recreation, scenic beauty and conservation. As well as their ecological and esthetic importance for urban residents, open spaces are used as leisure facilities in either active or passive mode. Availability of open space for public use is a key indicator of 'Livability' of cities to ensure health and wellbeing of citizens. The provision of ecosystem services that minimize the social stress rates of people living in densely populated urban areas is important for open space. Open space is a space that is planned to meet the needs of the community interaction and joint activities. Space also acts as a venue for children and adults to exercise, as well as a recreational space for adults and a green conservation area (Dewi et al., 2018).

The benefits of open space include environmental benefits, economic benefits, aesthetics, social and psychological benefits (Haq, 2011). Open space is the external public space where public areas are forming outside that can be accessed by everyone (public) such as city parks, Playgrounds, Amusement parks and others. By ensuring access to quality urban public space, UN-Habitat adopted a resolution on sustainable urban growth in 2011. The public spaces are both the 
group cohesion and fostering the health, enjoyment and for the betterment of all people and encouraging innovation, economic growth and sustainable environment. "Sustainable development goals, propo-sed 11 Goal 7, 2030, include universal access to public spaces and safe, inclusive and open green spaces, particularly for women and children, the elderly and people with disabilities" (Yuniastuti \& Hasibuan, 2018).

"Child Friendly City" means a city, town, community or any form of local governance dedicated to the fulfillment of the rights of children as laid down in the declaration on the Rights and protection of the Child. It is an area or culture in which children's views, interests; goals and rights form an integral part of public policies, programmes, and decisions (UNICEF, 2018). The Child-Friendly City is today at the top of the urban decision-makers 'agenda. This is particularly important given the increasing population of children in the urban areas of developing countries (Akbar \& Ali, 2012).

Unlike in the past, children in this present period are also no longer able to explore outdoor environments. The growing number of cars and the higher crime rate against a reduction in the number of open spaces close to home and a diminishing sense of community have made our town a less safe place to grow. This has adversely affected urban residents, in particular children whose freedom of movement has been undermined (Gazelle et al., 2012). It is important to study that the chances of children playing a role in the development of their own community and to stress their thoughts on this issue (Akbar \& Ali, 2012).

In Dhaka there is no specification of open spaces like playgrounds, parks or amusement parks for children and also no planning from the government or private organization regarding this matter. New policies, regulations and risk standards relating to the design of living space for children, especially their outdoor play and recreation space, need to be formulated (Driskell, 2002). Children are the link to the future of society and their involvement in urban planning is crucial. It is expected that relatively small improvements will have a significant effect on the lives of children in local play environments (Ahmed \& Sohail, 2008).

\section{Objective of the Research}

For the growth and development of children's emotion and behavior green open space plays a vital role but there are no objectives or aspects in the Ministry of Woman and Children Affairs (MoWCA) of Bangladesh regarding this matter? In fact there is no future planning to develop child friendly environment in the agenda of MoWCAT. This research paper aims to study on the importance of open spaces which will be helpful for the future development of child friendly environment in Dhaka.

\section{Literature Review}

\subsection{Why Child Friendly Cities?}

THE Demand FOR child friendly cities is grounded in the awareness that cities are home to a growing proportion of children around the world. However, most cities are overwhelmingly unfriendly to children and have policies that take few measures to meet children's needs and determine children's goals. In 2002, almost half of the world's children were residing in urban centers, most of them in low-and middleincome countries. Projections say that six out of ten children will live in urban areas of low-and middleincome countries by 2025 (UNICEF, 2002). Given the growing proportion of children residing in metropolitan areas across the country, most local officials appear ill-equipped to render their communities more child-friendly. Many city children in middle-and lowincome nations live in one-room tenements or shacks with their entire families, often without the most basic services or supports. Children in affluent families frequently reside in a environment where adults have no chance to play and socialize openly with their peers (Riggio, 2002).

\subsection{Initiative of the Child Friendly Cities}

The Child Safe Cities Project is a UNICEF-led program that assists cities and municipalities in their attempts to become child-friendly. This is also a network that brings together government and other partners such as civil society groups, the business sector, academics, the media and, most notably, children and child-led organizations who aim to make their cities and neighborhoods more child-friendly. The CFCI differs from country to country, representing 
the state of local children's rights and the institutional context (UNICEF, 2018). Various local, regional and national campaigns have been introduced nationwide to render communities more child-friendly, in the past 15 years. Experience has demonstrated that the adoption of children's rights at local level goes hand and hand with better working standards for all age groups of community (Schulze \& Moneti, 2007). The concept of a child-friendly community (CFC) has been created to enable municipal councils to take actions that are for children's best interests and to promote communities where children's rights to a healthy, caring, stable, educational, exciting, non-discriminatory, inclusive, culturally rich environment are discussed. The State has a responsibility to fulfill the interests and freedoms of children. It is the responsibility of local authorities to translate into effect at city level the commitments made at national level by States ratifying the declaration on the Rights and protection of the Child. Often, these may be based on measures made at the national level to help local authorities.

\subsection{Children in the Compact City}

Planners plan to accommodate singles, couples and the elderly in towns. As for the planners, family housing in the new developing town is already over-supplied and requires little encouragement. As a result, contemporary urban planning has become almost childblind, with the latest higher density centers being designed mainly for the childless. The talk is about 'vibrant' and 'liveable' mixed-use town centers, characterized by pavement cafés, restaurants and entertainment venues, shopping and office work. However, they are a long way from the traditional family-centric suburbs of the past, with a noticeable lack of natural play spaces. In Iran, the protection of children's rights in urban planning is almost a new concept. UNICEF may have taken the first significant measure to that effect after the Bam earthquake in southern Iran. However, it was only in 2000 that Evaz City in Fars Province was chosen as a CFC project in Iran. For the first time in Iran, Shiyeh wrote a book entitled "Prepare City for Children" which addressed the need to consider suitable urban spaces for children as well as how to address children's needs (Akbar \& Ali, 2012). Geneva offers plenty of green space for children. Geneva is recognized as the 'City of Parks' for more than a quarter of the city in parks and gardens. Such parks have a play area for children; some of them do have small pools. Geneva is also home to a stunning botanical garden abundant in flora and fauna. There's a little area of the garden where you can find deer, peacocks, swans, chickens, and goats in the enclosure (Cath, 2018).

\section{METHODOLOGY:}

The required data was collected from secondary source like Journals, articles, conference papers and websites. Observation was conducted with a purposive sampling method in which the research is done by observing the large-scale green open space in Greater Jakarta neighborhood that is considered to represent the urban character in Bangladesh. Flow of the research approach is given below-

\section{The research question}

-How much open space is important to create child friendly city?

\section{Theoretical framework}

-Open space, Child friendly environment and Open space scenario in Dhaka

\section{Research approach}

-Journals, Newspapers, Documents, Google

\section{Analysis technique}

-Qualitative analysis

\section{Conclusion}

-Strategies, Recommendation 


\section{Strategies for Implementation}

\subsection{Context of the Survey}

According to the 2001 census, Bangladesh has a population of roughly 123 million with a population density of 834 persons per $\mathrm{km}^{2}$. Bangladesh's capital, Dhaka City, experiences highly rapid urbanization and has one of the world's highest population densities of 14,939 citizens $/ \mathrm{km}^{2}$. From a small town with a population of only 200000 people in 1947, Dhaka grew to a city of 4.2 million in 1987 and has now become a mega-city of almost 20 million. Children under 18 make up around 48 percent of Dhaka's population. Not too long ago, Dhaka had a picture of a city with greenery and water bodies, but Dhaka has been one of the world's most polluted and crowded cities over the last few decades. Congestion, unplanned growth, and an increasingly increasing population have transformed Dhaka into a concrete jungle with insufficient space for outdoor play and recreation (Ahmed \& Sohail, 2008).

There are two types of leisure space in Dhaka City: open space for active leisure such as small play grounds, playgrounds, playgrounds, sports fields, stadiums, etc., and open space for passive recreationgardens, parks, parkways, green belts, botanical gardens, zoological gardens, etc. Playground, parks and amusement parks are the main outdoor open spaces in Dhaka in where children's play. While the number of amusement parks in terms of capacity and area is not very significant, it seems that these parks offer the only outdoor leisure space for children from high-and middle-income classes, and particularly for girls. This research consider-

a) Playgrounds - Public outdoor leisure areas especially for children; normally fitted with recreation facilities.

b) Parks - Enclosed pieces of ground kept for ornamentation and leisure in or near a city or town, and maintained as public property.

c) Amusement parks - Public or commercially operated parks with different amusement amenities (e.g. swings, water sports, gardens) and usually food and beverage booths (Ahmed \& Sohail, 2008).

UniversePG I www.universepg.com
Dhaka Metropolitan City has only 235 playgrounds against the requirement of 2400. Of those playgrounds, only 42 are open to the common people, while 16 are picked by unlawful occupants, 141 are institutional, 24 belong to different colonies and 12 are used as Eidgah. Women, children and the elderly suffer most from lack of playgrounds in Dhaka (The Financial Express, 2019). The ratio of outdoor play and leisure areas to Dhaka city's overall area is just 1:0.04, one of the lowest in the world. The city's open area was about 1266 acres in 2004, a significant decline from the 1916 acres in 1978 (Ahmed \& Sohail, 2008). Due to the exponential rise of population over the last several decades and the city corporation's continuing conquest of open space for lucrative commercial land usage, the area available for leisure and outdoor activities has decreased drastically.

\subsection{Open Spaces Scenario of Dhaka}

In the 1990 s, only $36 \%$ of Dhaka's core metropolitan area was under urban use and the remaining 64\% was non-urban or semi-rural. Regional Planning Project Survey (RDP, 2013) for the Dhaka Structure Plan (2016-2035) shows that 48 percent of the entire RAJUK area is in urban use and that the remainder is in non-urban use. The current stock of open spaces within the core city under separate jurisdiction is roughly 480 acres, while open spaces within the RDP district $(1,610$ sq.km) are just 1142,42 acres (4,62 sq.km) under recreational category.

In DAP (1,528 sq.km) there were 6962,54 acres $(28,17$ sq.km) of open spaces in all types including empty and unused land. In fact, the stock of open space is suffering from proper definition for children from planning perspective. According to the Forest, Wetland and Open Spaces Conservation Act 2002, Section (2), open space is defined as an area designated in the master plan as 'open space' or as 'open space' by government gazette notification. As a consequence, undetermined open spaces are still under danger of land grabbing and secret remnants of total stock are camouflage (Nilufar, 2015).

DAP has proposed the acquisition of 1590,6 acres of open spaces that will reach nearly $6 \%$ of the core urban area (DCC) for recreational purposes. According to the 
Open Space Requirement for DMDP Park / Children's Park (Local Park / Mini Park in the neighborhood) should be 1.5 acres per 12500 inhabitants and Play field (local play area) should be 3 acres per 12500 inhabitants. In the two city corporations, there is just 42 per cent open space for the public. Currently $84 \%$ of residents do not have access to green fields, parks and playgrounds, although only $16 \%$ have access to them (Daily Sun, 2019).

People live in 92 wards of Dhaka South City Corporation (DSCC) and Dhaka North City Corporation (DNCC) desperately requires at least 1,071 playgrounds, according to the study. For its 86 lakh population, Dhaka has 235 playing grounds. The survey also showed that in Lalmatia, Katsur and Mohammadpur the number of open spaces is comparatively higher than in other regions. There is no playground at all in Badda, Modhubag and Rampura (Daily Sun, 2019).

Government started constructing presumably the country's first playground for differently able children with special needs which is currently abandoned and no one can enter to use this place. The project was 4.16-acre land at the corner of Manik Mia Avenue and Mirpur Road, near the Jatiya Sangsad Bhaban by Public Works Department. Today this project is abandoned and no one can enter. It also noticed that the parks and playgrounds in the City are not open to women and children because of lack of protection and sufficient facilities. For children's physical, mental and social development, the progressive loss of playgrounds has had a negative effect. RAJUK has some strategy to protect and maintain some recognized public open space but there were no strategy plan for child friendly open space.

Ministry of Women and Children Affairs has some development plan for children like Sisimpur Program to provide early childhood education for children aged 0-5 years, Publishing books, periodicals and dictionaries suitable for children in order to instil in them respect for the mother tongue, Conducting programs on mental, intellectual and cultural development of children and Empowering adolescents by mobilizing them through clubs to bring in positive change in the society but it is clearly seen that there were no plan for outdoor activity for them (MoWCA, 2015-2016). This is also why children don't have an open space in which to play or learn anything. Government program is not suggesting any open space for child friendly environment in Dhaka. Of the 47 parks under Dhaka city corporations, only a handful now remains, according to Paribesh Banchao Andolan. Any big city needs enough open space but all authorities have ignored the demand for open spaces in Dhaka city for decades.

There is a strong and important connection, as psychologists and criminologists claim, between the occurrence of juvenile violence and the amount of parks, open spaces and playgrounds in the region. It is clear from the view of urban designers and scholars that there is a significant lack of political commitment on the part of the government and city officials to recover the parks and playgrounds from the land grabbers of Dhaka. Land grabbers and investors, leveraging their political leverage, are increasingly stealing parks, playgrounds and open spaces throughout the area. Not only are the wealthy neighborhoods consuming parks, but in many instances the local councils themselves have set up systems that jeopardize the core leisure purpose in open spaces.

The city authorities also authorized Dhaka Water Supply and Sewerage Authority to construct pumps within several parks and playgrounds in breach of the deal, while clubs have been permitted to create buildings within the facilities. The established open spaces are often not properly managed and occupied by drug users, thugs and goons who render them inaccessible to ordinary people and children. In 2000, the government passed a bill on the conservation of playgrounds, open fields, parks and natural water sources in urban areas, but the legislation is barely implemented (New AGE Opinion, 2018).

Open spaces are exceptionally scarce in Dhaka relative to both other large cities, and guidelines established by the World Health Organization. Dhaka City counts less than $1 \mathrm{sq} \mathrm{m}$ of green space per resident (between 0.05 and $0.5 \mathrm{sq} \mathrm{m}$ per capita, depending on the source) and this is shy of the WHO guidelines that recommend $9 \mathrm{sq}$ 
$\mathrm{m}$ per capita by more than one order of magnitude. By contrast, New York City has a land region of 23.1 square meters per capital (WBB Trust, 2015).

\subsection{Recommendation}

It is evident from the report that there was not only no sufficient open space for children, but also no government organization's initiative to build a more open space for children and establish a child-friendly climate. There were a few open areas for children in Dhaka, but there was no development programme to convert it into a playground or a children's park. After whole study there is a proposal for a policy agency, developer and builder to establish an open space in the future as a consequence of the development of a childfriendly city in Dhaka.

1. RAZUK should enforce the current and planned Open Spaces Strategic Position and also establish an open space for infants. They will avoid open space infringement and unwanted occupancy of child friendly open space.

2. Take effective steps to safeguard and conserve the open spaces of the supervisory agencies.

3. Visit, monitor and record the child's open space status every six months.

4. Ensure the efficiency and accessibility of children's parks and greenery. Open spaces such as parks, playgrounds and amusement parks should be structured with a proper biotic and abiotic dimension such that they will benefit from the atmosphere that will also support their physical and mental growth.

5. Ensure the protection, safety and wellbeing of children in public spaces.

6. Build warmth and ease for all children (healthy or with physical or mental limitations).

7. Creating visual beauty and alignment with the nature of the local environment.

8. Provide guidance on the success of the game and the power of the construction equipment.

9. Build green open space in densely populated places such as Dhaka, which will support children's mental development.

UniversePG I www.universepg.com
10. Build a playground within the neighborhood, and if space is small inside the city, establish a wider open area outside the town.

11. Mark all previous free and green lands under the DAP and reserve some of them for children's playgrounds and parks in a suitable place for each city and population of Dhaka.

12. The government will then restore the current parks, playgrounds and green spaces in the cities to avoid any potential encroachment.

13. By so doing, the authorities must maintain the routine management and protection of open spaces.

14. The playgrounds of the city belong to government schools. Such playgrounds will be left available to non-governmental school children so that they can play there openly. There would be no ban on children from other schools in the same community where there is no playground.

\section{CONCLUSION:}

Play Grounds and open fields function, quite simply, as the lungs of a community that offers its inhabitants a breathing room and their younger generation a chance to grow healthily. So the government will then restore the current parks, playgrounds and green spaces in the cities to avoid any future encroachment and prepare new planning to create more open spaces for children. This needs that authorities ensure routine maintenance and protection of open spaces. Conscious people are also responsible for getting organized and placing pressure on the government in this way. Planners and decision-makers should apply a child friendly lens to policies that impact children-especially in designing and planning playgrounds, parks, and amusement parks. Play is not only about providing children with healthy playgrounds and parks, it is important to protect their freedom and explore their physical and social world on their own terms. It is hoped that these recommendations will make Dhaka, and cities in general, more child-friendly, ultimately producing required open spaces for children. 


\section{ACKNOWLEDGEMENT:}

Author wishes to thanks Urban and Regional Planning Department of BUET and co-author.

\section{CONFLICT OF INTERESTS:}

The authors declared no possible conflicts of the interest with respect to the research, authorship and publication of this article.

\section{REFERENCES:}

1. Ahmed, A. \& Sohail, M. (2008). Child's play and recreation in Dhaka City, Bangladesh. Municipal Engineer 161. 4: 263-270.

https://passportsandadventures.com/most-familyfriendly-cities-in-the-world/

2. Ahmed, K. \& Sohel, M., (2008). Child's play and recreation in Dhaka City, Bangladesh. Municipal Engineer: Proceedings of the Institute of Civil Engineers. 161(4):263- 270. https://repository.lboro.ac.uk/articles/Child_s_pl ay_and_recreation_in_Dhaka_City_Bangladesh/ $\underline{9451799}$

3. Akbar, K. \& Ali, E. K. (2012). Planning ChildFriendly City (CFC) From Children's Perspective (Case Study: Quchan). Bagh-E Nazar. 9(20): 51-62.

https://www.sid.ir/en/journal/ViewPaper.aspx?I $\mathrm{D}=253747$

4. Cath, X. (2018). The Most Family-friendly Cities in the World. Passports and adventures, Family travel around the globe. Retrieved from -

https://passportsandadventures.com/most-fam ilyfriendly-cities-in-the-world/

5. Daily Sun. (2019). Dhaka lacks adequate open spaces.

https://www.daily-sun.com/amp/post/391265

6. Dewi, O.C., Chairunnisa, I., Hidayat, T., Anggraini, M. \& Napitupulu, A. (2018). Green Open Space: Awareness for Health or Sustainability?. IOP Conference Series Earth and Environmental Science, 120(1): 012014. https://doi.org/10.1088/1755-1315/120/1/012014

7. Driskell, D. (2002). Creating Better Cities with Children and Youth: A Manual for Partici- pation, Earth scan/UNESCO, London/ Paris. https://doi.org/10.1680/muen.2007.160.2.97

8. Gazelle, A. J., Dola, K., Yusof, M. J. M., \& Fang, L. M. (2012). Child-friendly City, Sustainable Tropical Environmental Design Exhibition. Faculty of Design and Architecture, Universiti Putra Malaysia. 4: 110-111. http://stedex.upm.edu.my/286/

9. Haq, S. M. A. (2011). Urban Green Spaces and an Integrative Approach to Sustainable Environment. J. of Environmental Protection. 2(5): 601-608. https://doi.org/10.4236/jep.2011.25069

10. Islam MJ. (2020). Factors influencing family size: a critical study on Khulna district of Bangladesh, Br. J. Arts Humanit., 2(4), 73-81. https://doi.org/10.34104/bjah.020073081

11. Ministry of Women and Children Affairs. Chapter 7: 81-95. https://mof.portal.gov.bd/sites/default/files/files/ mof.portal.gov.bd/page/5e31763f_f5b2_4ecb_bf 9a_edc8609d2f3f/G-1_06_30_Women_Englis $\underline{\text { h.pdf }}$

12. New AGE Opinion. (2018). Dhaka city needs parks and playgrounds. https://www.newagebd.net/article/39061/dhakacity-needs-parks-and-playgrounds

13. Nilufar, F. (2015). Preserving open space for livability of Dhaka. Public Space for all" World Habitat Day 2015 Seminar organized by Housing and Public Works Ministry, GoB. https://www.academia.edu/19511365/PRESERV ING_OPEN_SPACE_FOR_LIVABILITY_OF_ DHAKA? auto $=$ download

14. Riggio, E. (2002). Child friendly cities: good governance in the best interests of the child. Environment \& Urbanization. 14(2): 45-58. https://doi.org/10.1177/095624780201400204

15. Schulze, S. \& Moneti, F. (2007). The Child Friendly Cities: the case of Denver, USA. Institute of Engineering's-Municipal Engineer. 160(2): 97-102.

16. The Financial Express. (2019). City people have access to only 42 playgrounds. https://today.thefinancialexpress.com.bd/last-pag e/city-people-have-access-to-only-42-play groun ds-1557422442 
17. UNICEF, (2002). Poverty and Exclusion among Urban Children. Innocenti Digest, No.10.

https://www.unicef-irc.org/publications/pdf/dig est10e.pdf

18. United Nations Children's Fund (UNICEF). (2018). UNICEF Child Friendly Cities and Communities Handbook.

https://www.unicef.org/iran/media/2401/file/CF CI\%20Handbook\%20-\%20English.pdf
19. Yuniastuti, E. \& Hasibuan, H. S. (2018). Child-friendly green open space to enhance the education process for children. IOP Conf. Series: Earth and Environmental Science, 243(2019): 012161. https://doi.org/10.1088/17551315/243/1/012161

20. WBB Trust. (2015). Parks and playgrounds in Dhaka: taking stock and moving forward. https://healthbridge.ca/images/uploads/library/dh aka-park-report_final.pdf

Citation: Hossain ST., and Tasnim Z. (2020). Study on the importance of open space due to create Dhaka as a child friendly city, Asian J. Soc. Sci. Leg. Stud., 2(5), 96-103. https://doi.org/10.34104/ajssls.020.0960103 क) के 